\title{
Do shadow banks create money? 'Financialisation' and the monetary circuit
}

Jo Michell

March 2016

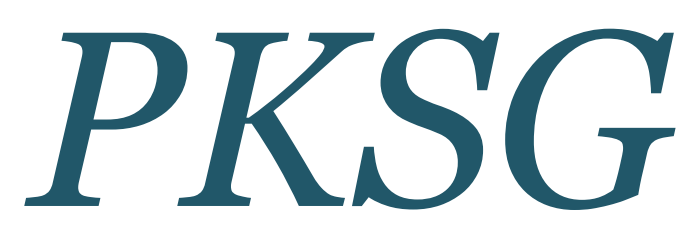

\section{Post Keynesian Economics Study Group}

Working Paper 1605

This paper may be downloaded free of charge from www.postkeynesian.net

\section{(C) Jo Michell}

Users may download and/or print one copy to facilitate their private study or for non-commercial research and may forward the link to others for similar purposes. Users may not engage in further distribution of this material or use it for any profit-making activities or any other form of commercial gain. 


\title{
Do shadow banks create money? 'Financialisation' and the monetary circuit
}

\begin{abstract}
The rise of the shadow banking system is viewed through the theoretical lens of Graziani's Monetary Theory of Production. Graziani's categories of 'initial finance' and 'final finance' are used to analyse the new forms of credit created in the shadow banking sector. It is argued that the accumulation of leverage in the shadow banking system and the creation of credit money by the traditional banking sector are symbiotic processes. While Graziani's triangular debtor-bank-creditor relationship remains central, the circuit operates in a perverse form in which household debt is stored on the balance sheets of shadow banks, allowing the banking system to break the historical connection between money creation and productive activity.
\end{abstract}

Keywords: monetary circuit, endogenous money, shadow banking, financialization, Graziani

JEL classifications: E12, E40, G21

Acknowledgements: This paper has benefited directly from comments made by Victoria Chick, Yannis Dafermos, Nick Edmonds, Daniela Gabor, Photis Lysandrou, Zoltan Pozsar, Engelbert Stockhammer, Andrew Teasdale and Don Webber and from comments made by participants at the Eastern Economic Association Meeting in New York and the UCL money and credit group.

Jo Michell

University of the West of England, Coldharbour Ln, Bristol BS16 1QY, UK

jo.michell@uwe.ac.uk 


\section{Introduction}

Shadow banking is the point of intersection between banking and marketbased finance. It was at the centre of the global financial crisis of 2008-yet attempts to deal with it from a theoretical perspective remain limited. The economics literature approaches the phenomenon the same way it approaches traditional banking — as a mechanism to overcome market imperfections, particularly imperfect information. Writers in international political economy instead view the rise of the shadow banking system as a way to evade regulation. There have been few serious attempts to analyse the shadow banking system from the point of view of monetary economics. Graziani's theory of the monetary circuit $(1990 ; 2003)$ provides an analytical framework which can be used as the basis for such a task.

Two views on the shadow banking system can be distinguished: the market view and the money view. The market view of shadow banking sees the phenomenon as the rise to dominance of disaggregated market-mediated financial transactions, and emphasises such activities as dealing in securitised debt. In this view, money and banking are demoted in significance relative to arms-length market-mediated financial transactions. The money view instead posits that the shadow banking system should be seen as an analogue to the traditional banking system because it performs bank-like functions such as maturity and credit transformation. Holders of this view argue that, rather than market intermediation, shadow banking is an extension of banking because shadow banks issue money.

These two views are critically evaluated here by drawing a parallel with 
Graziani's categories of 'final finance' and 'initial finance'. In Graziani's schema, initial finance refers to the creation of new purchasing power when banks lend to capitalists. Newly created bank money is used by capitalists to initiate production: workers are hired and intermediate goods purchased. Final finance refers to the bank-issued money which, after the production and sale of output, flows back from workers to capitalists when workers convert saved money balances into holdings of financial liabilities issued by capitalists. This allows capitalists to repay bank loans, destroying the previously created money.

In this paper it is argued that the statement that shadow liabilities are money is not immediately valid from a circuitist perspective because these financial claims cannot be used either as a means of payment for goods and services or as a means of settlement for financial contracts. Nonetheless, the credit chains which exist in the shadow banking system do hold many of the characteristics of bank intermediation and operate through institutions which are closely connected to - and in many cases directly owned by — banks. Rather than money - in the sense of means of payment - the liabilities issued by the shadow banking system are near-monies: liquid short-term stores of wealth.

It is argued that the expansion of such near-monies is reliant on the ability of the traditional banking system to endogenously create new credit money. This credit money is extinguished when savers exchange bank money for shadow bank liabilities. Despite holding money-like characteristics, shadow liabilities should therefore be classified as 'final finance' in Graziani's schema. Credit expansion, particularly for mortgage lending, therefore relies on a 
symbiotic relationship between traditional and shadow banks. Shadow banks are reliant on traditional banks for the endogenous expansion of credit, while traditional banks rely on the shadow banks as a storage facility for credit claims which exceed the capacity of traditional bank balance sheets.

\section{The circuit, 'financialisation' and shadow banking}

Following the tradition of Wicksell (1936), Hayek ([1935] 2012) and Schumpeter ([1938] 2008) the roots of Graziani's theory lead through Dennis Robertson to Keynes, who in the early 1930s made an appeal for a "Monetary Theory of Production" (Fontana \& Realfonzo, 2005). Graziani and his followers reject theories of capitalism in which money is a veil over barter and insist on the incorporation of money as a fundamental element of analysis in such a way that money is non-neutral and strictly endogenous (see Argitis et al., 2014, for a summary).

Graziani lays out a concise and remarkably clear macroeconomic model in which bank-issued money-deposits - are used as means of payment. As such, lack of savings can never constrain investment because access to finance in the form of newly-created bank deposits will ensure that saving adjusts to match investment expenditure. The problem faced by capitalists is not that saving may be insufficient to cover desired investment, but that initial finance in the form of new bank lending may not be forthcoming. Once production has been financed, capitalists hope to replace bank credit with long-term 


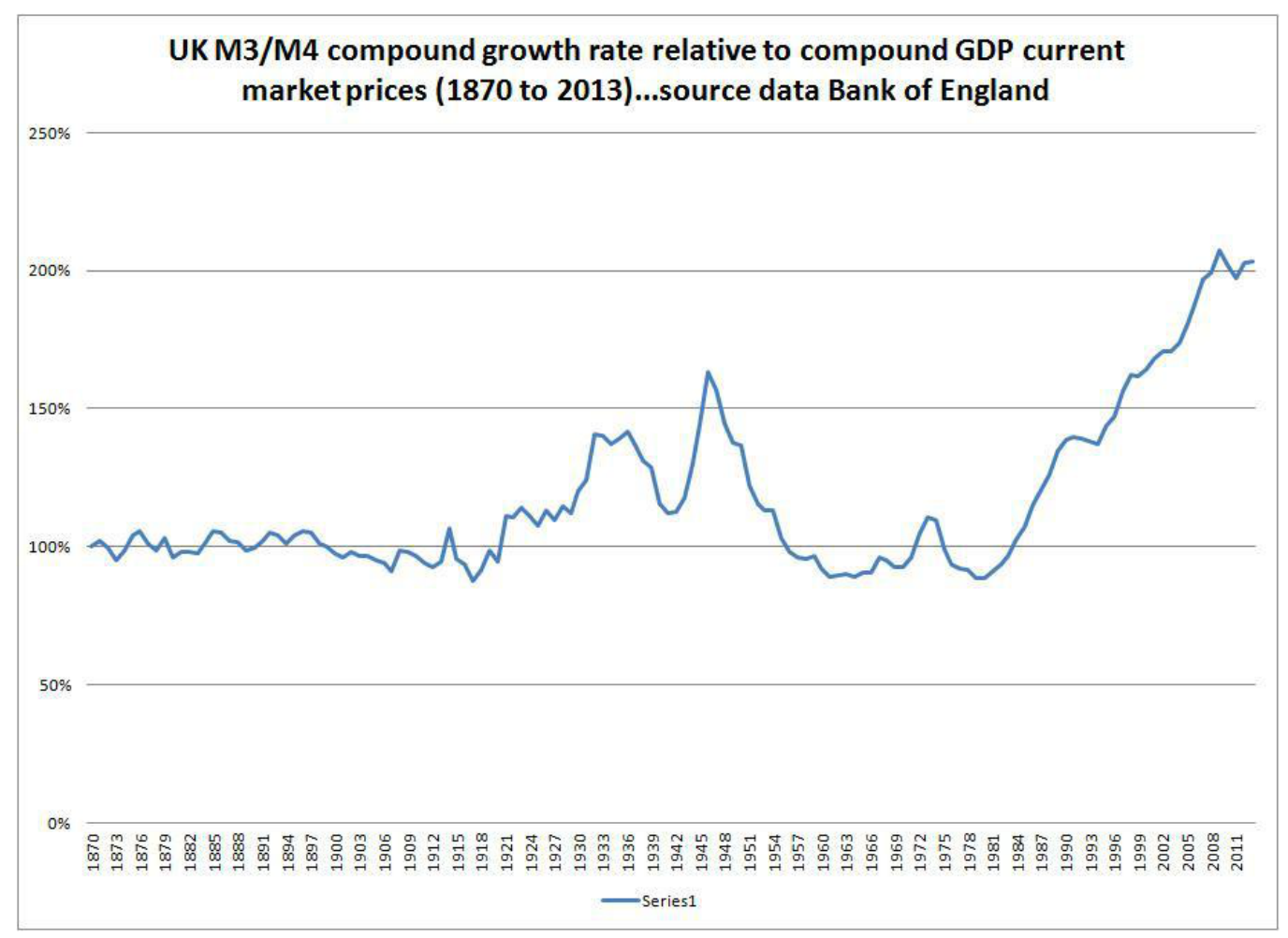

Figure 1: Long-run growth of UK money supply relative to GDP. Source: Bank of England

funding in capital markets. In this way, they avoid reliance on the continuing willingness of bankers to expand lending and to roll over previous loans. The distinction between bank financing and capital market funding - which Graziani labels 'initial finance' and 'final finance' respectively-is central to the analytical framework.

Graziani was, however, writing about a world less complex than that of today's financialised capitalism. The assumption that bank credit is mainly used by capitalists for the financing of production may have been true in the past, but is impossible to defend today. The majority of bank credit in the US and UK takes the form of mortgage lending to households (Turner, 2013). 
As a result, the tight link posited by Graziani between output and new bank lending - and thus the change in the money supply-no longer holds. This is illustrated in Figure 1 which shows the growth rate of broad money versus the growth of GDP in the UK.

Another important development since Graziani developed his theory is the rise of 'financialisation'. The term remains ill-defined (see Michell \& Toporowski, 2014) but refers to the changing role of financial institutions, the deepening penetration of financial activities and actors into everyday life, and the increasing financial activity of non-financial corporations. One important element in this shift is the rise of 'shadow banking'. Like 'financialisation', the term is imprecise, but relates to a blurring of the boundary between capital market and banking activities. Banks have increasingly operated in financial markets, both on the the asset side of their balance sheet by dealing in securities, and on the liability side by issuing their own securities, often collateralised against assets held on their balance sheet (the 'originate-to-distribute' model). The 'financialisation' period has also seen the emergence of non-bank entities which deal in financial markets and possess balance sheets which have many of the characteristics of those of banks. In particular, these institutions engage in maturity transformation-funding themselves with short term instruments (such as asset-backed commercial paper and repos) while holding assets of longer maturities - and in credit transformation - by using financial engineering techniques such as asset pooling and tranching to reorganise credit risk (Noeth \& Sengupta, 2011). Significant volumes of such activity now take place on the balance sheets of institutions which do not issue deposits and are thus not eligible for state 
insurance of their liabilities or for access to central bank liquidity provision facilities.

A number of contributions have been made which attempt to update the circuitist model for the era of financialisation, such as Seccareccia (2012); Passarella (2014); Sawyer (2013). These analyses reverse the sectoral balances assumed in Graziani's model and - in line with contemporary experiencecast the non-financial firms sector as the main creditor of the system and the household sector as the main debtor. ${ }^{1}$ This replaces Graziani's traditional depiction of credit relationships in which capitalists borrow to finance production, workers save, and banks and financial markets intermediate between the savers and borrowers. It is argued that the corporate sector has switched from productive activity to rentier behaviour while the rise of trading in markets for securities and derivatives is characterised as casino-type activity. 'Financialisation' is then conceptualised as a dysfunctional rentier outgrowth from capitalism, and one that must therefore inevitably be short-lived.

This analysis has been criticised by Lysandrou (2014), who argues instead that financialisation is a necessary and logical phase of capitalist development and that the view that increased financial trading represents only speculative and rentier activity is inaccurate. Lysandrou argues that the aggregative approach of the monetary circuit, organised around the triangular bank-household-firm relationship, is inappropriate for the analysis of a phenomenon characterised by rising dominance of atomistic market-based transactions:

\footnotetext{
${ }^{1}$ These discussions also tend to substitute Graziani's class analysis of workers and capitalists with the more neutral modern terminology of households and corporations.
} 
The crux of the matter is that a methodological framework that takes the aggregate monetary circuit as its basic unit of analysis is simply not flexible enough to accommodate the new reality of financialisation ... (Lysandrou, 2014, p. 19)

It is argued here that the basic unit of analysis of circuitist theory, the borrower-bank-lender triangular relationship, remains fundamental to an understanding of contemporary monetary and financial systems. Nonetheless, the theory of the monetary circuit needs to be updated to accurately reflect the institutional realities of modern financial systems. Graziani's distinction between initial finance - the creation of new money through bank lending - and final finance - the purchase by of financial assets - provides a useful analytical tool with which to examine this new reality. In Graziani's model, workers surrender ownership of bank deposits, previously created by bank lending. This allows capitalists to repay loans, destroying money and closing the monetary circuit. Initial finance is extinguished and replaced with final finance.

A key insight is that a logical prerequisite for the granting of 'final finance' is the prior extension of 'initial finance'-the creation of new bank money. While the counterparties to credit transactions may have switched positions under contemporary capitalism, the logic of Graziani's statement still stands. Much of the growing mass of intermediation between ultimate lenders and borrowers, while appearing as arms-length financial relationships mediated through the shadow banking system, is reliant on the power of commercial banks to endogenously create loans and deposits. 
The rise of market-mediated financial transactions, in particular the rise of securities trading, is closely associated with the 'shadow banking' system. In 1993, D'Arista \& Schlesinger wrote of the '... emergence of an unregulated parallel banking system.' (1993, p. 2), while the term 'shadow banking' was first used by McCulley (2007). The term is not yet clearly defined. ${ }^{2}$ One way in which authors have attempted to demarcate the shadow banking sector from 'traditional banking' is to draw a distinction between regulated and unregulated financial activity. The 'regulatory arbitrage' view emphasises the ability of institutions outside of the traditional regulatory framework to undertake bank-like activities while avoiding capital and liquidity requirements (e.g. Schwarcz, 2011-2012; Gorton \& Metrick, 2012). These institutions also lack access to state insurance of their liabilities and to lender-of-last-resort facilities. An open definitional issue relates to the distinction between institutions and activities. Gabor (2013) criticises the focus on institutions and regulatory regimes on the basis that much 'shadow banking' activity in fact takes place on the balance sheets of 'traditional' banking institutions. Instead, it is argued, the distinction should be based on the type of intermediation activities that institutions engage in. An alternative definitional distinction is offered by Lysandrou \& Nesvetailova (2015), which categorises explanations for the rise of shadow banking on the basis of whether they rely on factors endogenous to the financial system - as in the regulatory arbitrage view - or whether exogenous factors, primarily concentration of wealth and associated demand for yield, are seen as the driving force.

\footnotetext{
${ }^{2}$ For an overview of the institutions and activities involved, see Pozsar et al. (2013); IMF (2014); Lysandrou \& Nesvetailova (2015)
} 
Key activities associated with shadow banking include securitisation, repurchase (repo) lending and derivatives trading. The ability to move assets easily between balance sheets, combine different classes of assets to create new securities and separately trade different components of risk has led to a decomposition of the lending process. Previously a loan was held to maturity by the originator, such that the risk associated with that loan-and with the financing of that loan - was held by a single entity. With the rise of shadow banking, the various components of risk can instead be distributed among a number of market participants.

The increasing emphasis on market-based finance and the shift by banks from lend-and-hold to originate-to-distribute are well documented. While the substitution of retail deposit funding for issuance of securities and repo borrowing has been highlighted as a key feature of the new financial landscape, the way in which this change affects the role of banks as creators of money is less well understood. If banks increasingly make loans with the intention of shifting them off their balance sheets via a securitisation process, what are the implications for the triangular borrower-bank-lender relationship which lies at the heart of the circuitist analysis? - What becomes of the additional money that is brought into existence at the point that the bank makes the loan? These questions are addressed in the following sections.

\section{The hierarchy of money and shadow banks}

It is widely argued that the short-term, highly liquid financial liabilities used to fund shadow-banking activities are new forms of money (e.g. Pozsar et al., 
2013; Pozsar, 2014; Gorton \& Metrick, 2012; Stein, 2012; Gabor, 2014). But what does it mean to declare that repos and other financial instrument are 'shadow money'? In particular, which functions of money do these liabilities replicate?

If the claim should be taken to mean that the liabilities of the shadow banking system operate as means of payment, this would imply a shift comparable in significance to the historical point at which bank deposits became acceptable as means of payment: 'the transition from goldsmiths providing safekeeping facilities to bank liabilities serving as the chief means of payment is the fundamental story in modern banking' (Chick, 2013, p. 149). But this function is not performed by the liabilities of shadow banks. Nor do they perform the function of final settlement of financial obligations. Instead, these authors emphasise the use of short-term liabilities as a liquid store of wealth, highlighting the ability of these assets to be converted on demand at par to 'money proper'.

This highlights an important issue: the forms in which money appears are not equal; money is hierarchical. A distinction can be drawn between money - final means of payment or settlement - and credit - the promise to pay or means of deferring final settlement. But "what looks like money at one level of the system looks like credit from the standpoint of the level above." (Mehrling, 2012, p. 1) ${ }^{3}$ Bank deposits are a promise by banks to pay cash on demand. But since these credit claims are acceptable for final payment in 'real' transactions, they are also money. ${ }^{4}$

\footnotetext{
${ }^{3}$ The idea of money as hierarchical debt-pyramid goes back further than Mehrling and is to be found in Minsky ([1986] 2008) and Lapavitsas (2003) among others.

${ }^{4}$ While the most widely used, bank deposits are not unique in being simultaneously
} 
Among the issuers of demand deposits, however - the 'traditional' banking system - these claims are the funding for the asset side of their balance sheet. Final settlement among these institutions must be made using reserve balances at the central bank. But this central bank-issued money can equally be viewed as credit in that such liabilities 'fund' the assets held on the central bank balance sheet. And while the liabilities of the central bank will usually be acceptable as means of final settlement for domestic transactions, this may not be the case for international transactions - or in domestic economies which have been 'dollarised'.

This distinction is not addressed in Graziani's theory, in which the central bank and commercial banks are consolidated into single money-issuing unit, and international transactions and financial flows are abstracted away. It is important, however, in attempting to analyse the shadow banking system. The primary activity of this system is the buying and selling of securitiessecurities which are, in general, collateralised by loans (or by other securities which are themselves collateralised by loans). Shadow banking therefore, in large part, involves the trading of already existing credit claims. When securities are bought and sold, the commodity which changes hands embodies not goods, but credit. What is sold is the promise, by a third party, of future payment in money-but the transaction nonetheless requires immediate settlement in money.

From a circuitist perspective, the question of which asset performs the credit claims and money: In the past, cheques and bankers drafts have played this dual role. Currently, electronic platforms such as PayPal and Apple Pay allow payments to be made with what are essentially on-demand-at-par claims on bank deposits. Bitcoin is an interesting case because it is neither a credit claim, nor yet widely accepted as means of payment. 
function 'money' - of means of payment and means of settlement among actors inside the financial system, the buyers and sellers of credit claims, is an interesting one. When credit claims are traded or fall due, whose liabilities will be accepted as final means of settlement? Depending on the institutions transacting, this function is performed using the deposits of traditional banks or the liabilities of the monetary authority - a point highlighted by one of the leading 'shadow money' theorists, Zoltan Pozsar:

... not all money claims are created equal. One area where money claims differ is in functionality, that is, whether they can be used for transactions, that is, for settlement purposes.

The net payments of dealers and money funds, and those of all other actors in the broader financial ecosystem, are settled using demand deposits, and net deposit flows between banks are settled via transfers of reserves between banks' reserve accounts maintained at the central bank. (Pozsar, 2014, p. 9)

When credit claims fall due, settlement requires receipt of assets higher up the pyramid than the credit claim itself. A holder of asset-backed commercial paper can require settlement in demand deposits. A holder of demand deposits can demand par conversion into banknotes. But a holder of demand deposits will be neither willing nor able to accept settlement either in the form of bank deposits issued by a different institution or by delivery of the par value of a particular asset-backed commercial paper issue - the assets held are a claim on banknotes. It is this asymmetry in settlement function 
which establishes the monetary hierarchy. ${ }^{5}$

What is the origin of these circulating claims on future income? The assets backing most securities circulating in the shadow banking system are loans of some kind; contracts which came into existence when one party surrendered means of immediate settlement-money - in return for deferred settlement - a promise of money at some point in the future.

In a financially primitive system based on commodity money, such lending requires prior saving to have taken place, such that accumulated commodity money can be then either deposited in a bank or used to purchase financial securities. ${ }^{6}$ This is not the case in a bank-based monetary economy. In such a system, the decision to lend does not rely on prior saving, so long as the lender issues claims that are widely accepted as means of payment. Put another way, the initiative in extending new credit does not necessarily lie with the ultimate creditor-banks may choose to lend without having first accepted deposits and without a prior decision to on the part of any individual to save. The quantity of money and bank credit is then determined in large part by the lending decisions of banks.

What of the lending undertaken by the shadow banking system? In the same way that banks create money whenever new loans are issued, a 'traditional' bank can fund the purchase of a security by issuing new demand

\footnotetext{
${ }^{5} \mathrm{I}$ am indebted to Nick Edmonds for this point.

${ }^{6}$ Strictly speaking, credit expansion requires two steps: both a prior saving and a decision to hold some portion of those savings as bank deposits or financial assets. These two decisions can be separated in time. The decision to save, if all savings are held as gold, will not lead to credit expansion. Likewise, a decision to swap hoarded gold for financial assets - leading to credit expansion - can take place without any change in current saving behaviour. It is also possible that purchasing financial claims on the secondary market will simply increase the price of those claims and not affect the volume of credit.
} 
deposits. Since such deposits are acceptable to sellers of securities as final means of settlement, the traditional banking system may obtain securities by issuing its own liabilities and providing them to sellers of securities. This is not the case for 'shadow' institutions which fund themselves by issuing liabilities which cannot be used for settlement purposes.

Despite the fact that large volumes of securitised lending appears on the balance sheets of non-monetary institutions, these institutions do not therefore have the same autonomy to expand credit as that of traditional banks. Instead, the creation of new credit either requires a prior decision to 'not spend', a shift in liquidity preference-leading to an increase in the holding of financial assets vis-a-vis deposits - or through the expansion of money and credit on the balance sheets of 'traditional' banks. Put another way, the circuitist and Post-Keynesian notion of endogenous money does not apply directly to the liabilities of shadow banks.

If off-balance-sheet liabilities are not acceptable as means of settlementin any type of transaction - what is the basis of the claim that shadow banks issue new forms of money? The argument is found in various forms in Claessens et al. (2012); Stein (2012); Pozsar (2014); Gabor (2014). Pozsar (2014) argues that a range of financial assets - short-term securities nearing maturity such as Treasury bills, overnight repo and the liabilities of money market funds - should be classified as money alongside demand deposits and central bank liabilities. Dealer-banks, money market funds and the Treasury should therefore be added alongside central banks and commercial banks to the list of money-issuing institutions. ${ }^{7}$

\footnotetext{
${ }^{7}$ If the liabilities of these institutions were not money, Poszar argues, the term 'shadow
} 
Pozsar discusses the hierarchical nature of these monetary liabilities but, while reference is made to Mehrling's (2012) hierarchy of money, the distinction between 'money' (means of immediate settlement) and 'credit' (a promise of future payment) is replaced with a two-way classification system based on (a) the proximity of liabilities to government-issued claims and (b) on the nature of the insurance mechanisms supporting these liabilities. Liabilities are categorised on the basis of whether the assets backing the liabilities issued are public, for example repo lending collateralised by government bonds, or private, for example repo lending collateralised by mortgage-backed securities. A second distinction is drawn between those claims which are insured by the taxpayer - demand deposits - and those which are insured by private institutions such as the monoline insurers. This classification system leads to a four-tier hierarchy of 'money' with publicly issued, publicly insured liabilities - central bank reserves and treasury bills - at the top and privately-issued, privately-insured liabilities - repos and money market fund shares backed by private securities - at the bottom. ${ }^{8}$

But given that these claims cannot be used as means of payment or final settlement, what makes them money? The definition offered by the shadow money theorists is the following: 'These instruments have one common attribute, which is that they promise to trade at par on demand. This makes banking' would be misleading: 'if lending without money creation does not qualify as banking, neither should capital market lending without money market funding qualify as shadow banking.' (p. 21)

${ }^{8}$ Ambiguity arises from Pozsar's choice of definition based on the assets backing the claims, rather than the institution issuing the claims. For example, if the central bank holds privately securities (as a result of quantitative easing, for example) in Pozar's taxonomy, cash and reserves issued by the central bank are no longer pure 'public' money. Likewise, if commercial banks issue publicly-insured deposits against holdings of government paper, such deposits are classified as pure 'public money'. 
them money' (Pozsar, 2014, p. 9, emphasis added)

Is the promise of convertibility at par into transactions balances sufficient to declare an asset 'money'? As late as the 1930s, Keynes excluded the deposits of commercial banks from his definition of 'money proper' (which he reserved for gold coin and the notes of the Bank of England) although such deposits had by then been convertible on demand at par for the best part of a hundred years (Chick, 2013). For Keynes, it is the eventual acceptance of claims on money as means of payment which allows them to become 'money proper'. While convertibility at par into 'money proper' plays an important role in making deposits acceptable as means of payment, it is a necessary but not sufficient condition.

By the 1950s, the widespread use of bank deposits (and notes) as means of payment led Schumpeter to argue that these balances were money:

... there is no other case in which a claim to a thing can, within limits to be sure, serve the same purpose as the thing itself: you cannot ride on a claim to a horse, but you can pay with a claim to money. But this is a strong reason for calling money what purports to be a claim to legal money, provided it does serve as means of payment. ... As a rule, an ordinary bill of exchange does not so serve; then it is not money ... Bank notes and checking deposits eminently do what money does; hence they are money. (1954, p. 35, emphasis added)

On this basis, the liabilities of shadow banks are not money. But Pozsar and others instead emphasise the use of such liabilities as highly liquid stores 
of value. If assets are immediately - or almost immediately - convertible at par into means of payment, then these assets may reasonably be regarded by the holder to be equivalent to holding deposits.

Such a view can be found least as far back as the 1930s, during debates about the 'Chicago Plan'- a proposal to require that demand deposits be backed with central bank reserves on a $100 \%$ basis. Henry Simons noted that restricting the supply of money in this way would likely lead individuals to shift balances into highly liquid close substitutes such as time deposits:

The fact that such deposits cannot serve as circulated medium is not decisively important; for they are an effective substitute medium for purposes of cash balances. (Simons to Irving Fisher, July 4, 1934, quoted in Goodhart \& Jensen, 2015)

Liquid balances held in the form of the liabilities issued by shadow banks may not be immediately used as means of payment but since they provide a nightly option to convert at par into money proper, they are a close substitute (Edmonds, 2015). The question, 'Are shadow bank liabilities money?' is, at least in part, a question about the relative weighting of the different functions of money. Since shadow bank liabilities must first be converted into payment systems money before they can be deployed as purchasing power, these liabilities substitute the immediate means of payment function for means of payment one step removed, while retaining the function of liquid store of value. In this respect, shadow bank liabilities have much in common with traditional savings deposits.

Circuitists and Post Keynesians have tended to emphasise different func- 
tions of money (Fontana, 2000; Deleplace \& Nell, 1996). The Post Keynesian analysis of money traditionally starts from a discussion of fundamental uncertainty and the resulting requirement for a liquid store of wealth which will ensure individuals are able to react to unforeseen circumstances and to postpone decisions on consumption and investment. Money provides a flexible link between the present and an uncertain future. Circuitists on the other hand emphasise the function of means of payment. After asserting that banks issue liabilities which perform this function, Graziani presents an account of how money enters the economic system, circulates through that system and accumulates as balances which are the counterpart to bank lending.

But drawing a sharp distinction between the two schools on this basis is not entirely accurate. Post Keynesian analysis does take account of the means of payment function - this is the reason, after all, that money is able to function so effectively as a liquid store of value - and circuitists provide a coherent account of the store of value function since the monetary circuit describes the accumulation of bank deposits as the savings of households (Fontana, 2000).

One issue that is less widely explored in the Post-Keynesian and circuitist literature is the role of the state in determining what counts as 'money'. The state's role, particularly through its ability to specify acceptable forms in which taxes can be paid, has recently been emphasised by neo-Chartalists (Bell, 2001; Goodhart, 2000). As already noted, Mehrling constructs a hierarchy of money on the basis of the distinction between means of payment and promise to pay - but he does not discuss the place of the state in that hierarchy, despite the fact that the institutions at the top of the pyramid - central 
banks - are now universally state-owned. On the other hand, Pozsar's hierarchy of money is constructed on the basis of a public-private distinction - such that publicly issued or guaranteed liabilities are safer and therefore more money-like-but ignores the means of payment function.

Aside from taxation, the link between the state and the function of means of payment lies with the role that the state plays in enforcing acceptance of bank money - designating legal tender. In particular, once private bank liabilities become widely acceptable as means of payment, the state faces a dilemma: "either to continue to regard bank "money" ... as none of their business, or to collaborate with the banks in maintaining the exchange of state money with bank money at par' (Chick, 2013, p. 150). The public's confidence that bank money will exchange at par for state money is an important factor in bank money gaining acceptance as means of payment - and once this acceptance is widespread, the state must play its part in ensuring that promise of convertibility can always be met. The state thus runs a franchise operation in which the private banking sector is permitted to earn a profit in return for their role in providing access to the means of payment function of state money:

What private commercial banks do as financial intermediaries is to expand the total quantity of money, while conserving the quantity of state issued money, by hiring out money's function as a medium of exchange for set periods of time and for a set interest charge. (Lysandrou 2015, p. 10)

Private 'traditional' bank money thus reproduces the means of payment 
function of state money. But what of the store of value function? In a fiat money system in which commodity money is absent, the lowest risk financial assets are always those issued by the state - whether these are monetary assets or promises to pay, such as bonds. This is because the state is the ultimate issuer of the 'money' of the system - the final means of settlementand can therefore always meet its commitments by printing new money.

What if the demand for safe liquid stores of value exceeds the ability of the 'traditional' banking system to supply them? Specifically, what if the demand for money as a store of value exceeds that of money as means of payment? ${ }^{9}$ One way to view the liabilities of the shadow banking system is to see them as an attempt by the private sector to replicate the liquid store of value function of state-issued money. This function has historically also been provided by private bank money-but will this remain the case if the demand for liquid stores of wealth exceeds the demand for money as direct means of payment?

\section{Who holds shadow liabilities?}

If the liabilities of shadow banks are primarily held as a liquid store of value, where does the demand for these liabilities originate? In answering, a distinction needs to be made between claims held between intermediaries within the financial system - funds, dealers and banks - and claims held by creditors outside the financial system - the 'buyside' in the current market vocab-

\footnotetext{
${ }^{9}$ There is a connection between this question and an earlier debate in the Post Keynesian literature on whether, in an endogenous money system, it is possible for the demand for money and the demand for loans to diverge. See Howells (1995); Lavoie (1999); Arestis \& Howells (1999)
} 


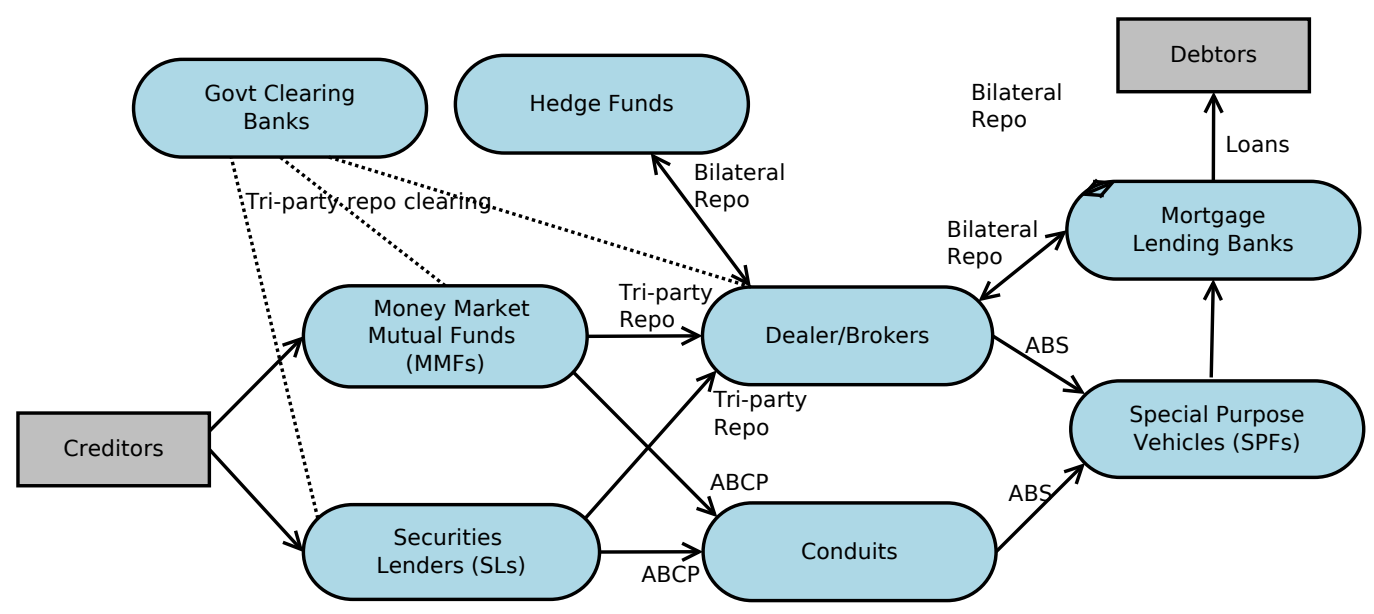

Figure 2: Shadow banking system

ulary. The motives for holding such claims and the mechanisms by which they transmit financial dynamics to the 'real' economy will differ between the two cases.

Figure 2 shows a stylised representation of the shadow banking system. The ultimate creditors of the system hold claims on money market mutual funds (MMFs) and large institutional securities lenders such as pension funds. These institutions lend to dealer-brokers and conduits using tri-party repo and asset-backed commercial paper (ABCP). Tri-party repo lending - and clearing - is done on the balance sheets of the big clearing banks, which also act as custodians for repo collateral. Bilateral repo markets connect dealer-brokers, hedge funds and traditional mortgage lending banks as well as providing a mechanism for inter-bank lending between traditional banks. 
Dealer-brokers hold the asset-backed paper (ABS) issued by special purpose vehicles (SPFs) which in turn fund securitised mortgages originated by mortgage lending banks.

The wholesale funding of traditional bank balance sheets is often misleadingly characterised as 'interbank' lending (e.g. Shin, 2010). In reality, as shown in Figure 2, wholesale funding represents the interface between large cash balances outside the financial system - the 'buyside' - and the balance sheets of banks and money dealers (Pozsar, 2014). In the 'shadow money' story, wholesale depositors such as the cash pools of corporations, securities lenders and 'don't-lose' portfolio managers are the ultimate creditors of the system but choose not to hold 'traditional' bank money because the size of the amounts greatly exceed deposit limits, thus exposing holders to default risk by individual banks. ${ }^{10}$ Instead, such institutions either hold assets such as MMF shares or lend directly to intermediaries such as dealer-brokers and conduits.

One influential 'shadow money' account of the 2008 breakdown of credit intermediation was the 'run on repo' story told by Gorton \& Metrick (2012). In this view, the ultimate creditors of the system provided funding for shadow banks holdings of securitised assets using repo credit. The refusal of creditors during the crisis to continue rolling over repos issued by dealer-brokers and conduits is seen as analogous to a traditional bank run.

This account suffers from a number of analytical flaws, not least the attempt to draw an analogy between the repo market and traditional banking

\footnotetext{
${ }^{10}$ Gabor (2013) notes that if this were the only reason for the holding of such assets, all that would be required to shut down the shadow banking system would be to remove the cap on state insurance of demand deposits.
} 
on the basis of a loanable funds analysis. The traditional banking system is described as an intermediary which accepts deposits of cash which are then lent on to borrowers - despite the fact that Graziani's assertion that money is created when banks undertake lending is now widely accepted, and the reserve balance money multiplier theory rejected (See, e.g., McLeay et al., 2014). ${ }^{11}$

Analytical flaws aside, the run on repo story also has empirical problems, as shown by Krishnamuthy et al. (2014). They examine data on shortterm lending during the crisis and find that, while tri-party repo lending did collapse during the crisis, the scale of lending through this channel was relatively small. Instead of using repo to fund their assets, shadow banking institutions predominantly relied on ABCP. Further, the degree of tightening in the tri-party repo market was much less severe than that which took place in the bilateral repo market. Since the latter is a mechanism not for funding assets but for allocating liquidity within the financial system, this tightening is more akin to a credit crunch than a bank run.

The other side of the 'shadow money' story focuses on the holdings of very short-term financial assets within the financial system. As intermediation chains have grown longer and the number of intermediaries involved in any credit transaction has grown, an uncertain world requires each link in the chain to ensure access to liquid balances which can be drawn upon in the event of shifts in market sentiment or unforeseen payment needs. In the

\footnotetext{
${ }^{11}$ 'In Step A, depositors transfer money to the bank, in return for a checking or savings account that can be withdrawn at any time. In Step B, the bank loans these funds to a borrower, who promises to repay through a mortgage on the property ... Bank solvency is promoted by requiring a fraction of deposits to be held in reserve' (Gorton \& Metrick, 2012, pp. 426-427)
} 
pre-crisis neoclassical world, in which money is a pure unit of account and liquidity issues were assumed away, such a requirement could be overlooked by academics and policy-makers - but these markets for repo and short-term commercial paper were at the centre of the deleveraging process which took place after the collapse of Lehman Brothers. The economics literature has since come to an ex post rationalisation of the collapse of asset prices and the associated disintermediation along the usual analytical lines in which problems result from maturity transformation, which itself emerges as a way to overcome asymmetric information and misaligned incentives (e.g. Brunnermeier \& Pedersen, 2009; Stein, 2012). But a convincing explanation as to why the financial system as a whole undertook a wholesale decomposition of lending into an ever greater number stages - each of them funded by liabilities of ever-shorter maturity - has yet to emerge. What is clear is that this process allowed financial institutions to find new ways to expand leverage and to squeeze capital and liquidity ever more tightly - it is, in this respect at least, a classic banking story.

But bilateral repo claims, given that they are claims between actors within the financial system, are not part of the monetary circuit - they neither fund the overall lending of the financial system nor operate as means of payment. Since credit and debit positions must logically sum to zero, viewed from outside of the consolidated financial sector these financial claims do not appear on any balance sheet. From the perspective of actors within the financial system, however, these claims create chains among institutions which connect external funding to ultimate borrowers. At each point along the chain, from shorter to longer-term intermediation, these instruments serve to allow 
the accumulation of apparently liquid stores of value on the balance sheets of financial intermediaries.

As emphasised by Post Keynesian theory, such liquid precautionary and transactions balances are held as a response to uncertainty - in this case, uncertainty over future moves of the markets in which institutions operate as dealers. The short-term financial instruments linking the nodes of the shadow banking system served - until the crisis at least - as an efficient way to finance the longer-term asset holdings on the other side of institutions' balance sheets but also as mechanism by which dealers could both maintain stocks of liquid assets and finance inventories of securities. As long as markets in these instruments and the assets backing them as collateral remained liquid, they also provided the illusion to the holder of providing an effective liquid store of value which may be converted into 'money proper' on demand at par.

But this will not be the case in situations of market illiquidity caused by lack of confidence in asset quality. Instead, with increasing interconnectedness of balance sheets and the potential for pro-cyclical leverage and liquidity dynamics these links provide new mechanisms by which instability is amplified (Gabor, 2013).

\section{Shadow banking and the monetary circuit}

Of the two types of off-balance-sheet activity described in the previous section, it is the lending of the 'buyside' to the consolidated financial system which can most easily be analysed using Graziani's analytical categories. The accumulation of large stocks of liquid assets on balance sheets outside 
of the financial system is the result of a macroeconomic process in which money balances are converted into money-like claims. Is this equivalent to Graziani's process by which 'initial finance' is converted into 'final finance' or is it just an extension of the process by which new bank lending creates new money: a broadening of the boundary of 'initial finance'? The answer seems to lie somewhere between the two extremes.

The credit relationships which emerge from the process of securitised lending have, at first glance, much in common with 'final finance'- the capital market funding which results from households purchasing the financial liabilities of firms. But Graziani's theory assumes that the result is a direct long-term credit relationship between borrower and lender-workers are assumed to hold directly the liabilities of capitalists. In the modern shadow banking system, however, buyside creditors hold the liabilities of financial intermediaries such as money market funds. These funds in turn hold the liabilities of other intermediaries. At the other end of the chain, an intermediary issues securities collateralised against the household debts held on its balance sheet. A household taking out a mortgage loan may not even be aware that its debt is no longer held by the loan originator. Since the balance sheets of financial intermediaries will not, in general, be 'matched book'each link in the chain will issue claims of equal or shorter maturity than the assets held on their balance sheet - the overall effect will be to produce a transformation of maturity and credit along the chain in the same way that such transformation takes place on the single balance sheet of a 'traditional' bank. The very short maturity of claims held by ultimate creditors, alongside the promise to convert at par-in comparison with the longer-term claims 
issued by non-financial corporations - gives these shadow bank liabilities a money-like character which may appear closer to 'initial finance'.

Graziani's theory posits that all claims in the credit system can ultimately be traced back to the creation of credit money by the banking system: in order for a household to purchase a financial security - a promise to paythey must first hold money as means of payment for that security. In a credit money system, that money will come into existence through the granting of a loan by the banking system (or through money-financed deficit spending of the government sector). Further, the initiative in lending lies not with a decision to lend on the part of the ultimate creditor but with the originating bank and the debtor.

Does this assertion still hold? The hierarchical nature of money and credit suggests it must: each of the securitised loans which ends up off-balance sheet must have have been originally purchased using, as means of payment, a financial claim further up the hierarchy. That financial claim will, in general, be a demand deposit with a traditional bank. This deposit, in turn will be matched by a loan elsewhere in the system since bank deposits creation relies on bank lending - resulting in the triangular creditor-depositor-debtor relationship. Bank lending and money creation is therefore a prerequisite for the endogenous expansion of shadow banking assets and liabilities. As Pozsar puts it: 'The vast majority of credit and money claims in the ecosystem begin life as a loan and the creation of a demand deposit in equal amounts.' (Pozsar, 2014, p. 33). The statement is equivalent in essence to Graziani's assertion that, in a monetary economy, 'initial finance' must logically precede 'final finance'. 
This process by which bank lending and money creation is transformed into a chain of shadow bank liabilities is illustrated in Figure $3 .^{12}$ The process is presented in stylised form in a sequence of five steps starting on the left of the figure. Five stylised balance sheets are represented: those of a creditor, a debtor, a mortgage-lending bank, a money market fund (MMF) and a dealer/broker bank. In the first step, the bank lends to a debtor household by issuing a mortgage loan, creating a deposit in the process. In the second step, the debtor household spends the newly obtained deposit (by purchasing of a house, for example) and the deposit is transferred to the balance sheet of a creditor household. ${ }^{13}$ The creditor household doesn't wish to hold a deposit and in the third step purchases a share in the MMF. The purchase is made by transferring ownership of the bank deposit from the bank account of creditor household to that of the MMF. The MMF has an excess of 'cash' and so it uses a repo to lend short-term to a dealer-broker - in the fourth step, the MMF exchanges the bank deposit for a repo asset. ${ }^{14}$ Finally, in the fifth step, the dealer-broker lends to the mortgage-issuing bank through the bilateral repo market - the 'interbank' market. This allows the mortgagelending bank to replace the deposit funding of its loanbook with repo funding. In the process, the deposit which was created when the bank made a loan

\footnotetext{
${ }^{12} \mathrm{~A}$ more complex analysis of the internal workings of the shadow banking system from a circuitist perspective is presented by Botta et al. (2015)

${ }^{13}$ In this example, the accounting is kept simple by assuming that all of the transactors hold deposit accounts at the same bank. In reality, this would most likely not be the case, so an additional set of balance sheet changes would take place with reserves moving between commercial bank balance sheets as payments are made for financial assets. Since this would increase the complexity of the example, this aspect of the banking system is abstracted away in order to focus on the chain of shadow banking intermediation.

${ }^{14}$ This would likely take place in the tri-party repo market so would involve one of the government clearing banks. Again, introduce an abstraction by collapsing the mortgagelending bank and the repo clearing bank into the same institution.
} 
is destroyed and initial finance is replaced with final finance as the circuit is closed. The final chain of claims is shown in the right-hand panel. 


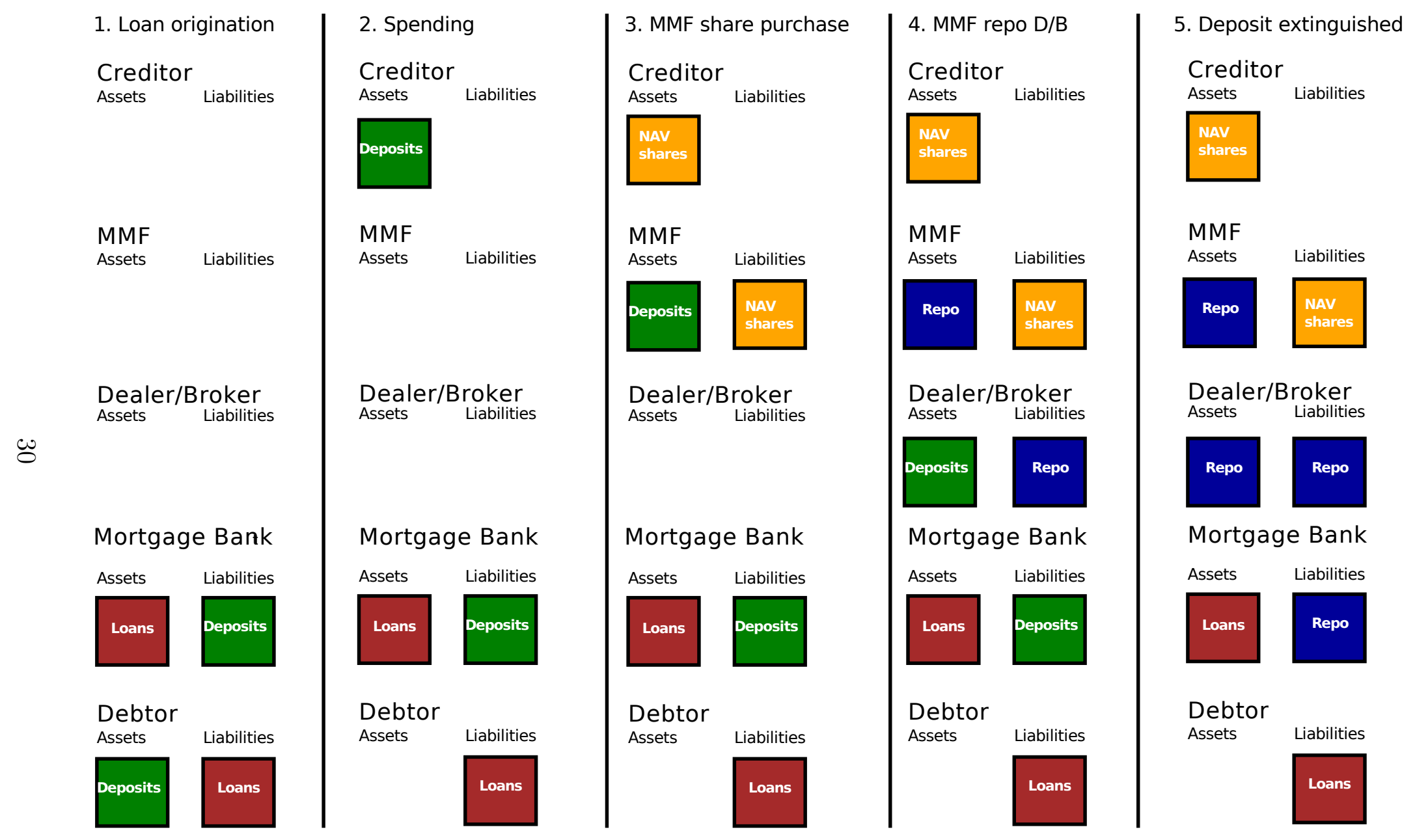

Figure 3: Shadow banking monetary circuit 
In this view, the shadow banking system can be seen as a 'loan storage' facility in which money claims are crystallised into less liquid, yet short-term claims - claims which exhibit many features of money, yet are not - not yet, in any case - 'money proper'. In the process of transferring credit claims onto the balance sheets of shadow banking institutions, the deposit created when the bank originally made the loan is destroyed, and the monetary circuit closed - allowing banks to initiate the circuit once again by creating a new loan and a new deposit, without reducing their (on-balance sheet) liquidity or capital.

But this is a perverse and mutated form of the monetary circuit. ${ }^{15}$ In Graziani's vision, money is created in order to finance production. It circulates through the economic system and is destroyed when workers either spend wages or use their unspent wages to buy securities, allowing capitalists to repay loans and close the circuit. In the shadow banking era, the majority of money and credit claims are created when banks lend to households. When this money is spent it ends up either in the hands of wealthy individuals or as corporate profit. Such wealthy individuals or corporations, in turn use the money to buy the liabilities of money market funds or other financial intermediaries. From here, money is passed along the links of the chain until is it used to simultaneously remove a loan from the balance sheet of a bank, and extinguish a deposit. In this way, the monetary circuit has escaped the constraints of real output.

\footnotetext{
${ }^{15}$ Passarella (2014) uses the term 'paradoxical'.
} 


\section{Conclusion}

Graziani's monetary theory of production provides a clear and elegant account of the processes of financing of production and monetary circulation in a capitalist system in which the means of payment is produced ex nihilo by banks. With the 'financialisation' of capitalism over recent decades, the role of money has changed to the extent that Graziani's theory, in the original, no longer provides an accurate depiction of the contemporary monetary circuit. Instead, the modern circuit operates in a perverse and mutated form. The circuit opens with lending to households and closes when household debts are moved off banks' balance sheets to be held in the shadow banking system. The counterpart assets to these off-balance sheet debts are the short-term liquid assets of corporations and high-net-worth individuals.

The new forms of credit relationships mediated by the shadow banking system have characteristics of both banking and market-based finance but, from a circuitist perspective, these claims are not money because they cannot be used as final means of settlement. In this respect they are closer to Graziani's 'final finance'. A corollary of this is that Graziani's assertion that 'initial finance' must precede 'final finance' remains valid: the accumulation of claims in the shadow banking sector logically relies on the prior creation of money claims by the 'traditional' banking sector.

In gaining access to a 'warehousing' facility for debt claims, the monetary circuit is able to escape the confines of production and serves to both accommodate and reinforce rising income inequality, increasing concentration of wealth, and inflation of asset prices. 


\section{References}

Arestis, P., \& Howells, P. (1999). The supply of credit money and the demand for deposits: a reply. Cambridge Journal of Economic, 18(1), 115-119.

Argitis, G., Evans, T., Michell, J., \& Toporowski, J. (2014). Finance and crisis: Marxian, institutionalist and circuitist approaches. Working Paper 39, Financialisation, Economy, Society and Sustainable Development (FESSUD).

URL http://fessud.eu/wp-content/uploads/2013/04/Finance-andcrisis-Marxian-Insitutionalist-and-Circuitist-Approaches-WP$39-1 . p d f$

Bell, S. (2001). The role of the state and the hierarchy of money. Cambridge Journal of Economics, 25(2), 149-163.

Botta, A., Caverzasi, E., \& Tori, D. (2015). Financial-real-side interactions in an extended monetary circuit with shadow banking: Loving or dangerous hugs? International Journal of Political Economy, 44(3), 196-227.

Brunnermeier, M. K., \& Pedersen, L. H. (2009). Market liquidity and funding liquidity. Review of Financial Studies, 22(6), 2201-2238.

Chick, V. (2013). The Current Banking Crisis in the UK: An Evolutionary View. In J. Pixley, \& G. Harcourt (Eds.) Financial Crises and the Natur of Capitalist Money: Mutual Developments from the work of Geoffrey Ingham, (pp. 148-161). Palgrave MacMillan. 
Claessens, S., Pozsar, Z., Ratnovski, L., \& Singh, M. (2012). Shadow banking: Economics and policy. Staff discussion note, International Monetary Fund.

D'Arista, J. W., \& Schlesinger, T. (1993). The parallel banking system. Briefing Paper 37, Economic Policy Institute.

Deleplace, G., \& Nell, E. J. (1996). Introduction: Monetary circulation and effective demand. In G. Delepace, \& E. J. Nell (Eds.) Money in Motion: The Post Keynesian and Circulation Approaches, (pp. 1-41). Basingstoke: Macmillan.

Edmonds, N. (2015). The "moneyness" of shadow bank liabilities. Blog entry.

URL http://monetaryreflections.blogspot.co.uk/2015/08/themoneyness-of-shadow-bank-liabilities.html

Fontana, G. (2000). Post Keynesians and Circuitists on money and uncertainty: an attempt at generality. Journal of Post Keynesian Economics, $23(1), 27-48$.

Fontana, G., \& Realfonzo, R. (2005). Introduction: The monetary theory of production. In G. Fontana, \& R. Realfonzo (Eds.) The Monetary Theory of Production: Tradition and Perspectives, (pp. 1-19). Basingstoke: Palgrave MacMillan.

Gabor, D. (2013). Shadow interconnectedness: The political economy of (European) shadow banking. Available at SSRN: http://ssrn.com/ abstract=2326645 or http://dx.doi.org/10.2139/ssrn . 2326645 . 
Gabor, D. (2014). The political economy of repo markets. Mimeo.

Goodhart, C. A. E. (2000). Can central banking survive the IT revolution? International Finance, 2(2), 189-209.

Goodhart, C. A. E., \& Jensen, M. A. (2015). A Commentary on Patrizio Lainà's 'Proposals for Full-Reserve Banking: A Historical Survey from David Ricardo to Martin Wolf'. Economic Thought, 4(2), 20-31.

Gorton, G., \& Metrick, A. (2012). Securitized banking and the run on repo. Journal of Financial Economics, 104 (3), 425-451.

Graziani, A. (1990). The theory of the monetary circuit. Economies at Sociétés, (7), 7-36. Also in Thames Papers in Political Economy (1989).

Graziani, A. (2003). The Monetary Theory of Production. Cambridge: Cambridge University Press.

Hayek, F. A. ([1935] 2012). Prices and production. In H. Klausinger (Ed.) The Collected Works of F. A. Hayek, vol. VII: Business Cycles Part I, (pp. 52-167). Chicago: University of Chicago Press. First edition, 1931, (London: George Routledge and Sons); originally published in German in 1929 as Presie und Produktione (Wien-Leipzig: Hölder-Pichler-Tempsky A.G.) Steele (2007).

Howells, P. G. A. (1995). The demand for endogenous money. Journal of Post Keynesian Economics, 18(1), 89-106.

IMF (2014). Shadow banking around the globe: How large, and how risky? In Global Financial Stability Report. 
Krishnamuthy, A., Nagel, S., \& Orlov, D. (2014). Sizing up repo. The Journal of Finance, $\operatorname{LXIX(6),~2381-2417.~}$

Lapavitsas, C. (2003). Social Foundations of Markets, Money and Credit. London and New York: Routledge.

Lavoie, M. (1999). The credit-led supply of deposits and the demand for money: Kaldor s reflux mechanism as previously endorsed by Joan Robinson. Cambridge Journal of Economics, 23(1), 103-113.

Lysandrou, P. (2014). Financialisation and the limits of circuit theory. Paper presentated at the Annual Workshop of the Post Keynesian Economics Study Group, SOAS, University of London, May 2014, available to download from http://postkeynesian.net.

Lysandrou, P., \& Nesvetailova, A. (2015). The role of shadow banking entities in the financial crisis: a disaggregated view. Review of International Political Economy, 22(2).

McCulley, P. (2007). Teton reflections. Global Central Bank Focus 2, PIMCO.

McLeay, M., Radia, A., \& Thomas, R. (2014). Money in the modern economy: an introduction. Bank of England Quarterly Bulletin, Q1, 1-10.

Mehrling, P. (2012). The inherent hierarchy of money. Prepared for Duncan Foley festschrift volume and conference, April 20-21, 2012.

Michell, J., \& Toporowski, J. (2014). Critical observations on financialization 
and the financial process. International Journal of Political Economy, 42(4), 67-82.

Minsky, H. P. ([1986] 2008). Stabilizing an Unstable Economy. USA: McGraw Hill. First edition (1986), New Haven: Yale University Press.

Noeth, B., \& Sengupta, R. (2011). Is shadow banking really banking? Tech. rep., The Regional Economist.

Passarella, M. (2014). Financialisation and the monetary circuit: A macroaccounting heterodox approach. Review of Political Economy, 26(1), 128148.

Pozsar, Z. (2014). Shadow banking: The money view. Working Paper 14-04, Office of Financial Research.

Pozsar, Z., Adrian, T., Ashcraft, A., \& Boesky, H. (2013). Shadow banking. Economic policy review, Federal Reserve Bank of New York.

Sawyer, M. (2013). Endogenous money, circuits and financialization. Review of Keynesian Economics, 1, 230-241.

Schumpeter, J. A. ([1938] 2008). The Theory of Economic Development. New Jersey: Transaction.

Schumpeter, J. A. (1954). History of Economic Analysis. London: George Allen \& Unwin.

Schwarcz, S. L. (2011-2012). Regulating shadow banking. Review of Banking E) Financial Law, 31, 619-642. 
Seccareccia, M. (2012). Financialization and the transformation of commercial banking: understanding the recent Canadian experience before and during the international financial crisis. Journal of Post Keynesian Economics, 35(2), 277-300.

Shin, H. S. (2010). Financial intermediation and the post-crisis financial system. Working Paper 304, Bank for International Settlements.

Stein, J. C. (2012). Monetary policy as financial stability regulation. The Quarterly Journal of Economics, 127(1), 57-95.

Turner, A. (2013). Credit, money and leverage: What Wicksell, Hayek and Fisher knew and modern macroeconomics forgot. Speech made at conference 'Towards a Sustainable Financial System', Stockholm School of Economics, 12 September.

URL http://ineteconomics.org/sites/inet.civicactions.net/ files/Adair $\% 20$ Turner $\% 20$ Stockholm $\% 20$ School $\% 20$ of $\% 20$ Economics $\%$ 20September\%2012.pdf

Wicksell, K. (1936). Interest and Prices. A Study of the Causes Regulating the Value of Money. London: Macmillan. Originally published as Geldzins und Güterpreise (1898), Jena: Gustav Fischer. 